\section{Temperature, But Not Ethephon, Influences Fruit pH of Processing Tomato}

\author{
A. Richard Renquist ${ }^{1}$, Jacinda M. English, and Jeff B. Reid \\ New Zealand Institute for Crop \& Food Research Limited, Box 85, Hastings, \\ New Zealand
}

Additional index words. Lycopersicon esculentum, fruit quality, fruit age, field environment

\begin{abstract}
The pH of processing tomato at harvest is a key quality criterion and is critical for safe product storage. Maximum allowable fruit homogenate $\mathrm{pH}$ is often 4.5. Our objective was to quantify the influence of air temperature on $\mathrm{pH}$, including any interaction with either fruit age or use of ethephon. Three planting dates were imposed as main treatments and ethephon as a subtreatment in a field trial, and each planting was harvested on four dates. Fruits were harvested from trusses tagged to identify three fruit age groups in sub-subplots. Temperature exerted primary control of tomato $\mathrm{pH}$. The relationship of bulk fruit $\mathrm{pH}$ to thermal time was curvilinear ( $\mathrm{pH}$ was always $<4.55$ ); however, when $\mathrm{pH}$ was related to thermal time from anthesis, a linear relationship resulted. The oldest fruit had a much higher $\mathrm{pH}(>4.5)$ than younger ones (mean $\mathrm{pH}$ for all dates $=4.3$ ). Ethephon did not alter these temperature/pH relationships.
\end{abstract}

Decades of research on the quality of processed tomato products have led to welldefined quality criteria for fresh fruit at harvest (Dadomo et al., 1994). These include total solids (\%), soluble solids concentration (SSC, measured as $\left.{ }^{\circ} \mathrm{Brix}\right), \mathrm{pH}$, titratable acidity, viscosity, and color intensity. The $\mathrm{pH}$ is often a critical factor. Safe storage of processed products requires fresh fruit homogenate to have a maximum allowable $\mathrm{pH}$, usually 4.5 . This is often achieved by choosing a suitable cultivar for the growing district. However, otherwise superior cultivars may not be utilized for lack of a single trait, such as sufficiently low $\mathrm{pH}$. Information on the effects of crop management (e.g., irrigation, use or avoidance of the hormonal harvest aid ethephon, or harvest timing) on $\mathrm{pH}$ of harvested fruit would be valuable. Results of ethephon trials have often been influenced by weather and other factors that vary with the season (Battilani, 1994), and most were done with earlier, thinner-walled cultivars (Bussell, 1973). Despite much research on agronomic influences, there are still large gaps in our understanding of how field environment or management influences fruit quality parameters.

There are a number of challenges in defining these influences in tomato, not the least of which is the 40-d variation in the age of fruit at once-over harvest. One practical consequence is the difficulty in selecting fruit samples for

\footnotetext{
Received for publication 21 Oct. 1999. Accepted for publication 5 June 2000. This work was supported in part by Heinz-Wattie, Ltd. Technical assistance by John Burry, Stuart Agnew, and Barry Sanders was much appreciated. The cost of publishing this paper was defrayed in part by the payment of page charges. Under postal regulations, this paper therefore must be hereby marked advertisement solely to indicate this fact.

${ }^{1}$ To whom requests for reprints should be addressed. E-mail address: renquistr@crop.cri.nz
}

testing. Generalizing environment-quality relationships for crops with different planting dates is also difficult, since their environments during a given stage will differ and crop developmental response may vary. The key relevant management decision is when to harvest (Grierson and Kader, 1986). The time of maximum usable yield has been widely used, but this does not result in the best quality. Fruit color is one guide to quality, but is not by itself a reliable index of maturity (Young et al., 1993) and its peak time is unlikely to coincide with the optimal times for several other important quality factors. We must integrate these factors to calculate a definitive best harvest time in relation to the crop's environment, rather than to rely on subjective ranking of target values for color, $\mathrm{SSC}, \mathrm{pH}$, and viscosity. The first step is to establish what controls each quality factor. This paper deals with control of one such factor, $\mathrm{pH}$.

The objectives of this research were to characterize the relationship of fruit $\mathrm{pH}$ to the crop field environment (including differences due to planting date), and to determine whether this interacts with either fruit age or the use of ethephon.

\section{Materials and Methods}

The 1997-98 experiment was located at the Crop \& Food Research station near Hastings, New Zealand. In the top $15 \mathrm{~cm}$ of the Mangateretere silt loam soil, the available soil $\mathrm{N}$, estimated by anaerobic incubation at $40^{\circ} \mathrm{C}$ (Keeny and Bremner, 1966), was $66 \mathrm{~kg} \cdot \mathrm{ha}^{-1} \mathrm{~N}$, Olsen $\mathrm{P}$ was $30 \mu \mathrm{g} \cdot \mathrm{mL}^{-1}$, exchangeable $\mathrm{K}$ was $1.14 \mathrm{meq} / 100 \mathrm{~g}$, cation exchange capacity was 24.1 , and $\mathrm{pH}$ was 6.1 . The soil was raised into beds on $1.5-\mathrm{m}$ centers $2 \mathrm{~d}$ before the first planting. Plant population was 22,200 plants/ ha, achieved using a within-row spacing of $30 \mathrm{~cm}$.
The main treatments imposed were three transplanting dates: 23 Oct., 14 Nov., and 3 Dec. 1997. Two-plant cell plugs were used. The subtreatment was ethephon (Ethrel $48^{\circledast}$, Rhone Poulenc, New Zealand) at $4.8 \mathrm{~g} \cdot \mathrm{L}^{-1}$ a.i., $240 \mathrm{~L} \cdot \mathrm{ha}^{-1}$ ), applied to half of each plot 12 to $16 \mathrm{~d}$ before predicted harvest (depending on forecast air temperature). Use of ethephon is a nearly universal commercial practice in New Zealand, to hasten foliar senescence and, thereby, aid harvest.

The 12 whole plots (three planting dates $\times$ four replicates) were three beds $(4.5 \mathrm{~m}$-wide $\times$ 16-m long), divided into 8-m-long ethephon subplots. The design used four randomized complete blocks, each containing subplots with the six treatment combinations. For each treatment, representative samples were taken for quality analyses from two plants in each of the four blocks at each of the four harvest dates. Additionally, within the middle row of each subplot there was a 3-m-long section where fruit age groups were defined (see below). Separate quality samples for each age group were collected from these.

Multiple harvests were used to develop a time course of $\mathrm{pH}$ change with crop environment. The first two of the four dates chosen were earlier than the conventional harvest time (date 3 ) and the last date was later. The intervals were based on weather conditions. The commercial harvest date is ideally a constant number of degree days after the application of ethephon (usually within 10-18 calendar days). Ethephon is applied after the fruit locular gel has softened enough that cutting the fruit does not cut more than two seeds on average.

At planting, fertilizer was applied in bands $5 \mathrm{~cm}$ from the plants and $5 \mathrm{~cm}$ deep, to supply 72,30 , and $84 \mathrm{~kg} \cdot \mathrm{ha}^{-1}$ of $\mathrm{N}, \mathrm{P}$, and $\mathrm{K}$, respectively, based on soil tests and a model of fertilizer response. The cultivar was 'Morse', an early to midseason cultivar, developed in California and the most widely planted cultivar here. (The specific cultivar number was confidential; seed was supplied by HeinzWattie, Ltd.). The crop was managed using normal commercial practices to control weeds, pests and diseases. Air temperature at the test site was measured every $2 \mathrm{~min}$ and daily max./min. values converted to thermal time (degree days, above an empirically determined base temperature of $7^{\circ} \mathrm{C}$ ).

Irrigation was scheduled based on weekly soil moisture measurements, using a Time Domain Reflectometry (TDR) instrument (Soil Moisture Equipment Co., Santa Barbara, Calif.). Soil water deficit in the upper $50 \mathrm{~cm}$ was kept below $60 \mathrm{~mm}$ during most of the growing season, a level shown to avoid deficit effects on tomato growth in past trials on this soil. Irrigation was withheld during the last 4-5 weeks prior to harvest, to reflect commercial practices.

Since all plots were sprinkler irrigated together, a compromise was required to allow the soil in the first plantings to dry and to avoid fungal diseases of foliage and fruit. As a result, plantings 2 and 3 had a longer preharvest period without irrigation. Based on prior research at this site (Renquist and Reid, 2001), 
the resulting soil water deficits (maximum of $102 \mathrm{~mm}$ in planting 3) would have had little or no effect on fruit $\mathrm{pH}$.

Plant and fruit measurements included frequent counting of flowering trusses to define three fruit age categories ("arcs" of trusses) in $3 \mathrm{~m}$ of the center row per subplot. The term "truss arc" has been used in tomato research as a visual concept related to fruit age, since the first-formed trusses are near the crown ( $\operatorname{arc} 1)$ and most of the youngest trusses are out at the periphery (arc 3 or 4) (Alvino et al., 1988; Julian, 1990). In this trial, three arcs were defined: arc 1 was the first eight trusses, arc 2 was trusses 9-20 and arc 3 was made up of trusses after 20. While flowering was well synchronized within plots, in some cases the last plants required up to a week to develop the required 8 or 20 flowering trusses to complete tagging of all trusses in an arc.

Fruit homogenate $\mathrm{pH}$ was measured using a glass electrode, temperature-compensated, $\mathrm{pH}$ meter (Radiometer, Copenhagen, Denmark) for 25-fruit samples from two plants per subplot on each of four harvest dates, referred to as bulk pH. These bulk samples of mixedage fruit were proportionally sampled by position across the bed, which has been empirically determined to be representative of the fruit population (proprietary method of HeinzWattie, Ltd.; from Alan Kale, personal commun.). In addition, samples were selected by arc number from two of the tagged plants in each subplot, using the first two fruit developed on each truss. Sample sizes were up to 25 fruit $(0.5$ to $1.5 \mathrm{~kg})$, using all available fruit when $<25$ were present.

\section{Results and Discussion}

When the results from all planting and harvest dates and all ages of fruit within plants were time-integrated appropriately, tomato $\mathrm{pH}$, measured on fruit homogenate, was found to be controlled by cumulative air temperature.

Fig. 1 shows the time trend in fruit $\mathrm{pH}$ over the four harvest dates for each of the plantings separately, with and without ethephon. These data were from bulk samples of mixed-age fruit. In the third planting, initial $\mathrm{pH}$ was lower, but it rose more sharply. A possible explanation for the low initial $\mathrm{pH}$ is that harvest dates were chosen in relation to ethephon application date. This was in turn based on a responsiveness test, where a fruit sample is cut to test the degree of locular softening. This occurred after fewer growing degree days than the two earlier plantings. Values were similar by the final harvest of each planting and had reached the $\mathrm{pH} 4.5$ limit of acceptability. There were no consistent significant effects of ethephon application on $\mathrm{pH}$, which simplifies interpretation. The analysis of variance (ANOVA) indicated that only the date of harvest had a significant effect, which supports the use of regression analysis.

When data for the three plantings were pooled, the relationship between thermal time and homogenate $\mathrm{pH}$ of mixed-age fruit was curvilinear (Fig. 2). Only the ethephon-treated plots were used, since that is the standard commercial practice in New Zealand (the shape was unchanged when untreated plots were included). The strong relationship $\left(r^{2}=0.93\right)$ implies that the rate of $\mathrm{pH}$ increase can be largely explained in terms of thermal time.

This relationship was checked in more detail by distinguishing between fruit age groups (Fig. 3). Although there were again upward trends in $\mathrm{pH}$ over the harvest period, there were distinct differences in $\mathrm{pH}$ among fruit age groups within each planting (tested by ANOVA). The oldest fruit ( $\operatorname{arc} 1$ ) had the highest $\mathrm{pH}$, which, for at least the last two harvest dates, exceeded the target $\mathrm{pH}$ of 4.5 in all three plantings. In contrast, the mean $\mathrm{pH}$ when combining both arcs 2 and 3 and the last two harvests was $4.33,4.32$, and 4.29 for plantings 1,2 , and 3 , respectively. This difference from arc 1 is very large in practical terms. Findings in Italy (Alvino et al., 1988) were similar in terms of the relative $\mathrm{pH}$ values between arc trusses, but differed in that $\mathrm{pH}$

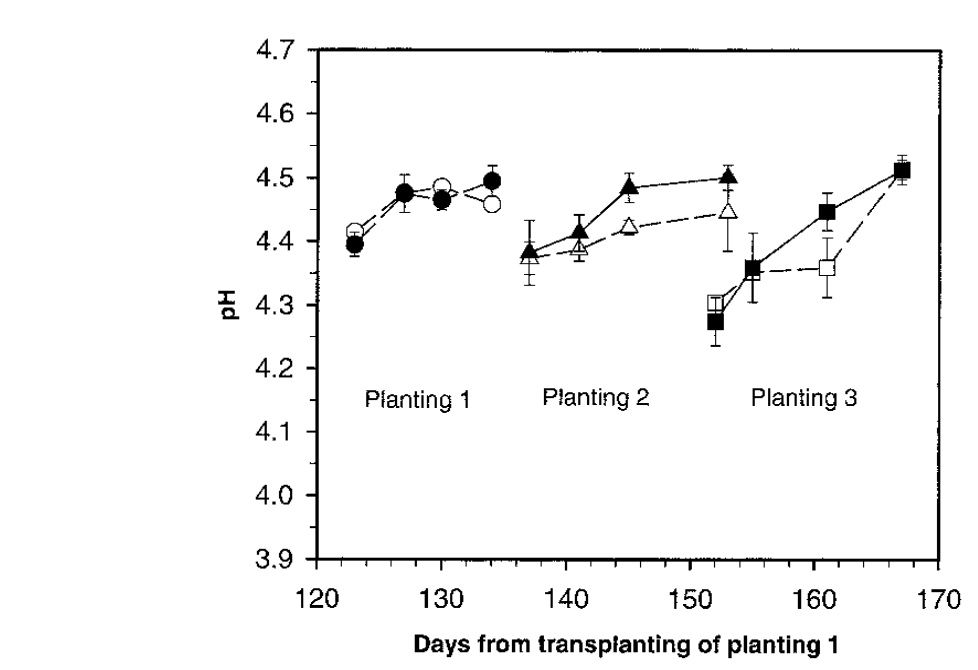

Fig.1. Effect of planting date and ethephon on tomato bulk fruit $\mathrm{pH}$ over four harvest dates per planting

(bars $=2 \times$ sE of means). Filled symbols indicate ethephon-treated plants.

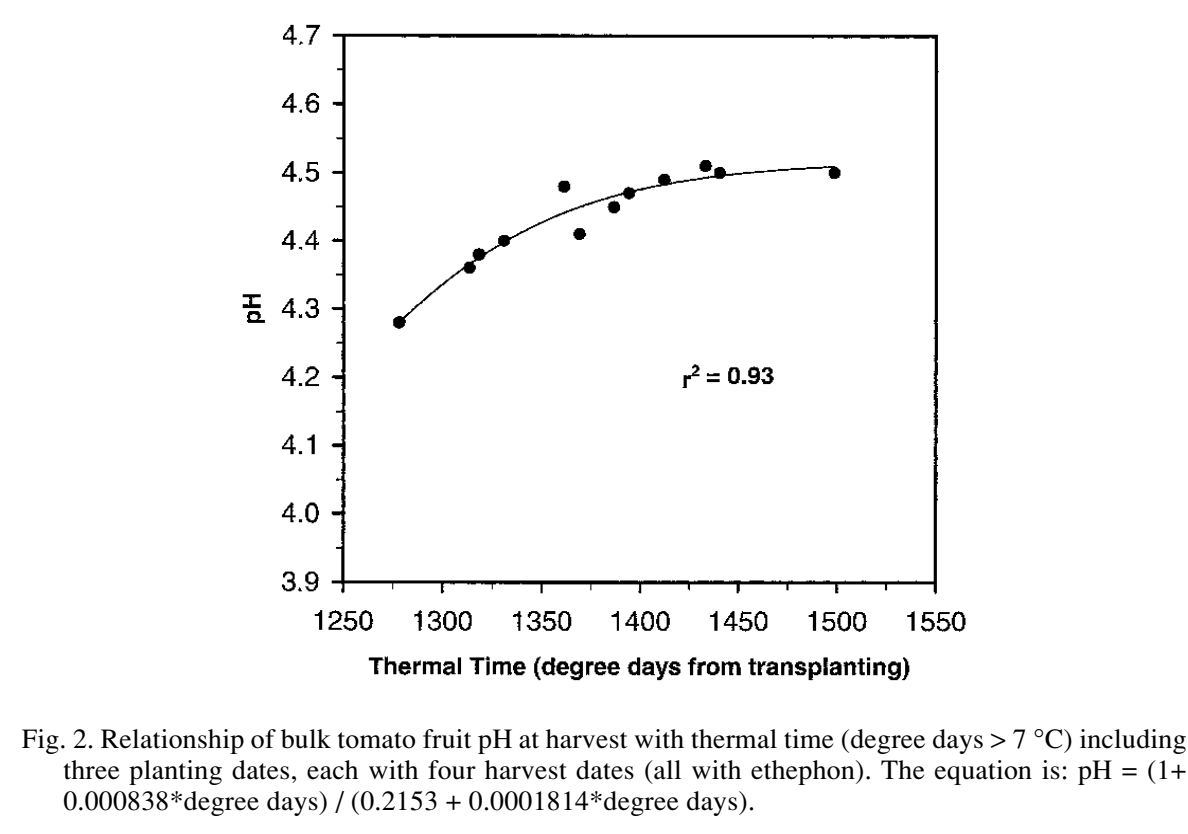

Fig. 2. Relationship of bulk tomato fruit $\mathrm{pH}$ at harvest with thermal time (degree days $>7^{\circ} \mathrm{C}$ ) including three planting dates, each with four harvest dates (all with ethephon). The equation is: $\mathrm{pH}=(1+$ $0.000838 *$ degree days $) /(0.2153+0.0001814 *$ degree days $)$.

stopped rising between the last two harvests. This difference from our results may have been a result of averaging $\mathrm{pH}$ values across three cultivars and/or timing harvest to the atest maturing cultivar in the Italian study.

By distinguishing between fruit age groups, the $\mathrm{pH}$ could be related to thermal time from anthesis rather than from planting time. For each age group, the average date of anthesis was within 3 to $4 \mathrm{~d}$ of all individual truss sponding to so the degree day value corremated closely. When the results from all truss arcs on all planting dates were pooled, the $\mathrm{pH}$ of individual fruit (or sets of same-age fruit) clearly increased linearly with thermal time after anthesis over the range of harvest dates studied, regardless of ethephon treatment (the two lines are both shown in Fig. 4. This is important fundamental knowledge to use, for instance, in a model of fruit quality in relation to crop development and environment. There are also two practical consequences. First, 


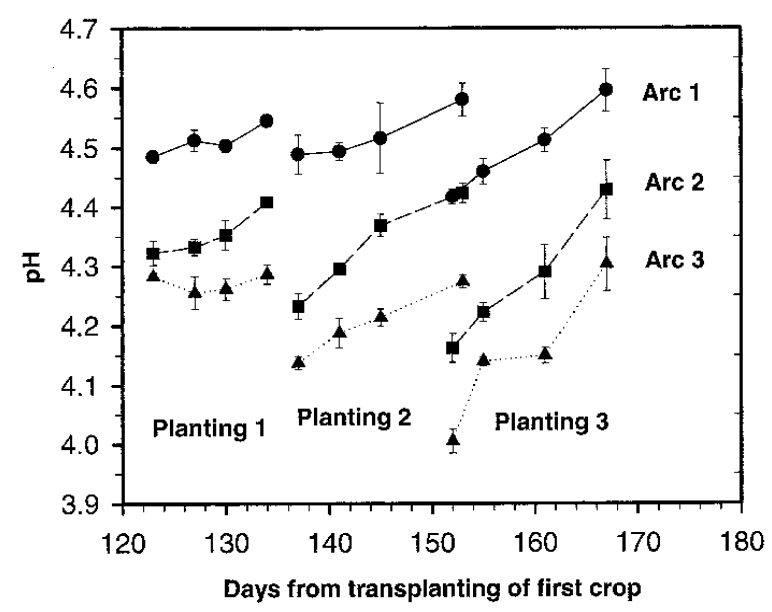

Fig. 3. Effect of planting date and fruit age group (truss arc) on tomato fruit $\mathrm{pH}$ (all with ethephon). Other details as in Fig. 1. Arc 1 is the oldest age group.

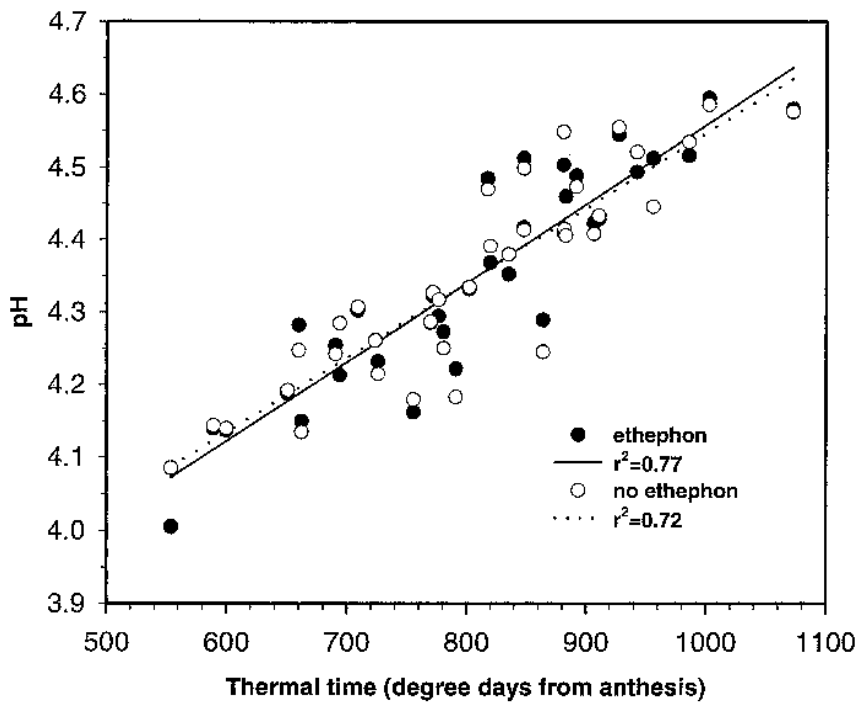

Fig. 4. Relationship between $\mathrm{pH}$ and thermal time from anthesis in each combination of planting date/harvest date/age group/ethephon. Filled symbols and solid line indicate ethephon-treated plants and fitted line. The equation with ethephon is: $\mathrm{pH}=3.515+0.001034 *$ degree days. homogenate $\mathrm{pH}$ is lowest in young fruit, so early harvests are important if $\mathrm{pH}$ must be kept low. Second, warm weather accelerates the rise in $\mathrm{pH}$, making early harvests even more desirable under those conditions. Of course, these $\mathrm{pH}$ criteria need to be integrated with those based on other tomato quality parameters, once those have been quantified.

\section{Literature Cited}

Alvino, A., R. d'Andria, and G. Zerbi. 1988. Fruit ripening of different tomato cultivars as influenced by irrigation regime and time of harvesting. Acta Hort. 228:137-146.

Battilani, A. 1994. Effect of irrigation, ethrel, and harvest date on yield and quality of processing tomato. Acta Hort. 376:299-306.

Bussell, W.T. 1973. Effect of soil moisture on ripening in dwarf tomatoes after ethephon treatment. N.Z. J. Expt. Agr. 1:381-382.

Dadomo, M., S. Leoni, A. Rodriguez, T. Koutsos, J.I. Macua, M.L. Taborda, C.M. Portas, and G. Gandolfi. 1994. Main results of the EEC Research Programme-Action C: Variability in relation with cultivar and country. Acta Hort. 376:43-50.

Grierson, D. and A. Kader. 1986. Fruit ripening and quality, p. 241-280. In: J.G. Atherton and J. Rudich (eds.). The tomato crop: A scientific basis for improvement. Chapman and Hall, London.

Julian, A.K. 1990. Flower and fruit development in processing tomatoes. MS Thesis, Massey Univ., Palmerston North, New Zealand (XD 0535).

Keeny, R.R. and J.M. Bremner. 1966. Comparison and evaluation of laboratory methods of obtaining an index of soil nitrogen availability. Agron. J. 58:498-503.

Renquist, A.R. and J.R. Reid. 2001. Processing tomato fruit quality: Influences of soil water deficits at flowering and ripening. Austral. J. Agr. Res. 52(8): (In Press.).

Young, T.E., J.A. Juvik, and J.G. Sullivan. 1993. Accumulation of the components of total solids in ripening fruits of tomato. J. Amer. Soc. Hort. Sci. 118:286-292. 